\title{
nirS-containing denitrifier communities in the water column and sediment of the Baltic Sea
}

\author{
S. Falk ${ }^{1,3}$, M. Hannig ${ }^{2,3}$, C. Gliesche ${ }^{1}$, R. Wardenga ${ }^{1,4}$, M. Köster ${ }^{1}$, K. Jürgens ${ }^{2}$, and G. Braker ${ }^{3}$ \\ ${ }^{1}$ Institut für Ökologie, Ernst-Moritz-Arndt-Universität, Schwedenhagen 6, 18565 Kloster, Hiddensee, Germany \\ ${ }^{2}$ Baltic Sea Research Institute, Seestrasse 15, 18119 Warnemünde, Germany \\ ${ }^{3}$ Max Planck Institute for Terrestrial Microbiology, Karl-von-Frisch-Str., 35043 Marburg, Germany \\ ${ }^{4}$ Institute for Chemistry and Biochemistry, Ernst-Moritz-Arndt-University, Soldmannstraße 16, 17487 Greifswald, Germany
}

Received: 7 April 2006 - Published in Biogeosciences Discuss.: 23 June 2006

Revised: 9 February 2007 - Accepted: 23 April 2007 - Published: 10 May 2007

\begin{abstract}
The aim of this study was to compare structural differences in the nirS-type denitrifying microbial communities along the environmental gradients observed in the water column and coastal sediments of the Baltic Sea. To link community structure and environmental gradients, denitrifier communities were analyzed by terminal restriction fragment length polymorphism (T-RFLP) based on $\operatorname{nirS}$ as a functional marker gene for denitrification. nirS-type denitrifier community composition was further evaluated by phylogenetic analysis of nirS sequences from clone libraries. T-RFLP analysis indicated some overlap but also major differences between communities from the water column and the sediment. Shifts in community composition along the biogeochemical gradients were observed only in the water column while denitrifier communities were rather uniform within the upper $30 \mathrm{~mm}$ of the sediment. Specific terminal restriction fragments (T-RFs) indicative of the sulfidic zone suggest the presence of nitrate-reducing and sulfide-oxidizing microorganisms that were previously shown to be important at the suboxic-sulfidic interface in the water column of the Baltic Sea. Phylogenetic analysis of nirS genes from the Baltic Sea and of sequences from marine habitats all over the world indicated distinct denitrifier communities that grouped mostly according to their habitats. We suggest that these subgroups of denitrifiers had developed after selection through several factors, i.e. their habitats (water column or sediment), impact by prevalent environmental conditions and isolation by large geographic distances between habitats.
\end{abstract}

\section{Introduction}

The Baltic Sea is one of the largest brackish water systems in the world (Meyer-Reil et al., 2000). After the last glaciation

Correspondence to: G. Braker

(braker@mpi-marburg.mpg.de) the Baltic Sea has been connected continuously with the Atlantic Ocean over the past 8000 years via the Danish straits (Sohlenius et al., 1996; Andrén et al., 2000; Sohlenius et al., 2001). These straits provide the only salt water supply from the North Sea. Water exchange with the North Sea depends on wind-induced movements (Meyer-Reil et al., 2000) and mainly affects the upper layers of the water column while water exchange in the deeper layers is quite rare and occurs approximately once in a decade (Feistel et al., 2003a, b; Nausch et al., 2003). In the Gotland Deep, one of the deepest basins in the central Baltic Sea, well-mixed surface water is separated from dense bottom waters by a halocline at about $70 \mathrm{~m}$ depth (Kotilainen et al., 2002). This barrier leads to frequent anoxic conditions in deeper waters and to accumulations of sulfide ( $\mathrm{S}^{2-}$ ) that diffuses out of the sediment. Therefore, low oxygen $\left(\mathrm{O}_{2}\right)$ and sulfidic conditions with concurrent availability of nitrate $\left(\mathrm{NO}_{3}^{-}\right)$at the suboxicsulfidic interface can be found in the water column (Brettar and Rheinheimer, 1991; Hannig et al., 2006).

Thus, conditions in the water column should be adequate for denitrification and it has been assumed that water column denitrification contributes significantly to the nitrogen budget of the Baltic Sea (Rönner and Sörensen, 1985). Significant denitrification activity has indeed been proven for the suboxic-sulfidic interface, indicating sulfide-driven chemoautotrophic denitrification (Brettar and Rheinheimer, 1991; Hannig et al. 2007).

Culture-independent approaches based on the analysis of functional marker genes for denitrification revealed the lowest denitrifier diversity in the suboxic-sulfidic interface in the central Baltic (Hannig et al., 2006). In contrast, cultivation-dependent approaches show the highest diversity and density of heterotrophic denitrifying bacteria (Brettar et al., 2001) with a predominance of Shewanella baltica and Pseudomonas sp. (Brettar and Höfle, 1993; Höfle and Brettar, 1996) in that interface. Furthermore, an epsilonproteobacterium, related to Thiomicrospira denitrificans was

Published by Copernicus GmbH on behalf of the European Geosciences Union. 


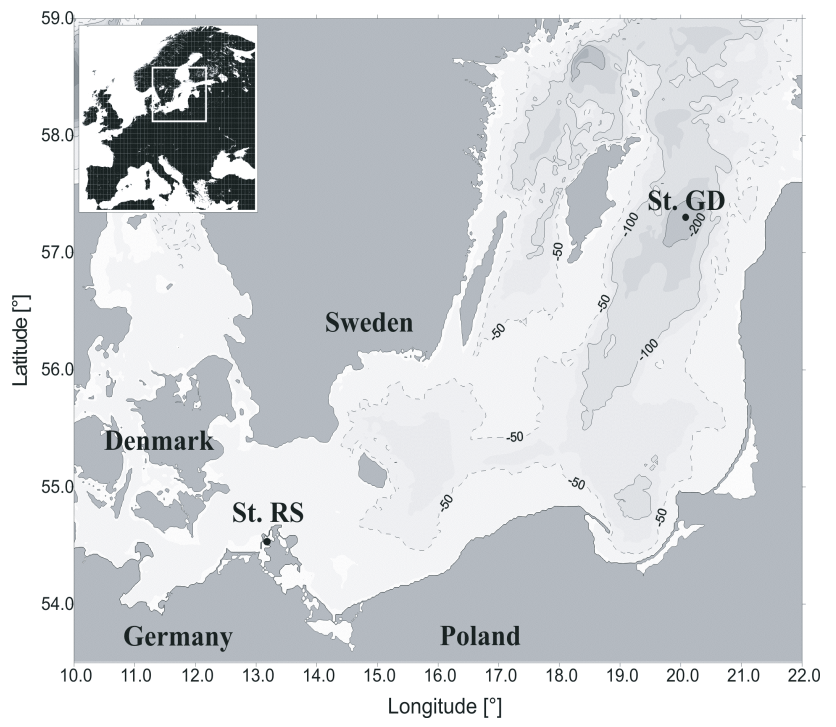

Fig. 1. Sampling stations in the Baltic Sea. Station Rassower Strom (RS) in the Bodden next to the island Rügen (Germany) and Gotland Deep (GD) in the central Baltic Sea (Map courtesy of Jan Donath, Baltic Sea Research Institute Warnemünde).

identified as an important chemolithoautothrophic sulfideoxidizer and nitrate-reducer (Labrenz et al., 2004; Höfle et al., 2005) and suggested to be predominantly responsible for autotrophic denitrification in the Gotland Deep (Brettar et al., 2006).

Heterotrophic and autotrophic denitrifiers reduce oxidized nitrogen compounds $\mathrm{NO}_{3}^{-}$and nitrite $\left(\mathrm{NO}_{2}^{-}\right)$to the gaseous intermediates nitric oxide and nitrous oxide and to dinitrogen as the end product in a dissimilatory process. Denitrifying bacteria are phylogenetically widespread, thus a 16S rRNA gene-based approach is inappropriate to explore the communities of organisms belonging to this functional group. nirK and nirS coding for copper and cytochrome $c d_{1}$ containing nitrite reductase, respectively, were used as functional marker genes to target denitrifiers in PCR-based approaches (Braker et al., 1998). Both enzymes are functionally equivalent and catalyse the reduction of $\mathrm{NO}_{2}^{-}$to $\mathrm{NO}$, which is the key reaction in denitrification (Zumft, 1997). These genes have been targeted to study denitrifier communities in a variety of habitats such as soils (Avrahami et al., 2002; Priemé et al., 2002), aquifers (Santoro et al., 2006), waste water treatment plants (Throbäck et al., 2004) and marine habitats (Braker et al., 2000; Liu et al., 2003; Jayakumar et al., 2004; Castro-González et al., 2005; Hannig et al., 2006). Studies of these communities in marine habitats indicated that denitrifier diversity and community structure in the water column and sediments of the world's oceans were at least in part determined by environmental gradients of $\mathrm{O}_{2}$, $\mathrm{NO}_{3}^{-}, \mathrm{NO}_{2}^{-}$and $\mathrm{S}^{2-}$ (Liu et al., 2003, Castro-Gonzalés et al., 2005, Hannig et al., 2006).
Although data on denitrifier diversity in different aquatic and terrestrial habitats are rapidly accumulating, the principal differences in denitrifier composition between sediment and water column are not known. The Baltic Sea is an ideal system for this comparison of denitrifier community structure as gradients in $\mathrm{O}_{2}, \mathrm{NO}_{3}^{-}$and $\mathrm{S}^{2-}$ occur both in the water column (e.g., in the central basins), at the scale of meters, and in coastal sediments (e.g. in the Bodden in the southern Baltic Sea), at scales of $\mathrm{mm}$ to $\mathrm{cm}$. The Bodden at the "Nordrügensche Boddenkette" are formed by the accumulation of sand, which separates areas of shallow water from the outer Baltic Sea (Meyer-Reil et al., 2000). The water column in these shallow water areas is mixed thoroughly, therefore anoxic conditions occur only in the sediments. There is evidence that coastal sediments are very important in removal of riverborne nitrogen by denitrification (Voss et al., 2005). Denitrification rates have been measured in Baltic sediments (e.g. central Gulf of Finland) using the isotope pairing method (Tuominen et al., 1998). This study revealed that the bulk of denitrification was coupled to $\mathrm{NO}_{3}^{-}$production by nitrification. However, in the Bodden sediment only small amounts of $\mathrm{NO}_{3}^{-}$were produced by nitrification at the aerobic-anaerobic interface resulting in low summertime denitrification rates in this area (Dahlke, 1990). Besides denitrification, anaerobic ammonium oxidation (anammox) also contributes to nitrogen loss in coastal sediments (Thamdrup and Dalsgaard, 2002; Risgaard-Petersen et al., 2004).

Here, we studied communities of denitrifiers in the water column of the central Baltic Sea and in coastal sediments using a culture-independent approach by applying the functional marker gene nirS amplified from community DNA. Shifts in nirS-type denitrifier communities along biogeochemical gradients were analysed by terminal restriction fragment length polymorphism analysis (T-RFLP) as a fingerprint technique. Additionally, nirS genes from the Bodden sediment were cloned and included into a phylogenetic tree comprising all nirS sequences from marine habitats available from public databases. Analysis of these sequence data suggests that the heterogeneity of nirS genes is driven by the different ecological niches that the respective marine denitrifiers occupy. These niches seem to be defined by the habitat, water column or sediment, shaped by the prevalent environmental conditions, and can be isolated by large geographic distances.

\section{Material and methods}

\subsection{Study area and sampling}

Two different sites in the Baltic Sea were studied, namely Rassower Strom which is located in the "Nordrügensche Boddengewässer" $\left(54^{\circ} 33^{\prime} \mathrm{N}, 13^{\circ} 12^{\prime} \mathrm{E}\right)$ for sediment sampling, and the Gotland Deep ( $240 \mathrm{~m}$ water depth) in the central Baltic Sea (Baltic Sea monitoring station $271 ; 57^{\circ} 19^{\prime} \mathrm{N}$, 
$20^{\circ} 03^{\prime} \mathrm{E}$ ) for water column sampling (Fig. 1). Water samples were collected at the Gotland Deep during a cruise in August 2004. Coastal sediment samples were taken in July 2004 at the Rassower Strom, a shallow water coastal inlet of the southern Baltic Sea (4 m water depth). Since the water column in these shallow water areas is continuously mixed by wind, anoxic conditions occur only in the sediments. Sampling at the Gotland Deep was performed on board the R/V "A. v. Humboldt" with a rosette water sampler (51) mounted on a Seabird CTD-system measuring profiles of temperature, conductivity, oxygen $\left(\mathrm{O}_{2}\right)$, fluorescence and turbidity. For DNA extraction, seawater was filtered immediately after sampling through Durapore ${ }^{\circledR}$ filters (0.2 $\mu \mathrm{m}$; Millipore, Billerica, MA, USA). The filters were snap-frozen in sterile reaction tubes in liquid nitrogen and stored at $-20^{\circ} \mathrm{C}$. Sediment samples were collected on board of the R/V "Prof. F. Gessner" with a multicorer (Black et al., 2002). Two subsets of samples were analyzed from the same core. First, for PCR amplification and cloning of nirS genes three subsamples from the top $30 \mathrm{~mm}$ were taken based on the oxygen distribution as follows: (1) 0-5 mm (of which the upper $2 \mathrm{~mm}$ were oxic); (2) 5-12 $\mathrm{mm}$ (suboxic layer); and (3) $12-30 \mathrm{~mm}$ (sulfidic layer). A second set of subsamples was obtained by slicing the sediment at $1,2,5,7$, and $10 \mathrm{~cm}$ depth. The corresponding layers ( 0 to 1,1 to 2,2 to 5,5 to 7 and 9 to $10 \mathrm{~cm}$ ) were homogenized and used for T-RFLP analysis of nirS genes. Measurements of chemical parameters and DNA extractions were performed within $1 \mathrm{~h}$ after sampling.

2.2 Determination of chemical parameters in samples from the water column and sediment

Oxygen, nitrate/nitrite $\left(\mathrm{NO}_{3}^{-} / \mathrm{NO}_{2}^{-}\right)$, sulfide $\left(\mathrm{S}^{2-}\right)$ concentrations and $\mathrm{pH}$ were determined for samples from both sampling sites. In water samples, $\mathrm{O}_{2}$ was measured by the Winkler method (Grasshoff, 1983). Ammonium was determined in the water column with the modified indophenol blue method (Koroleff, 1983). Nitrate was reduced to $\mathrm{NO}_{2}^{-}$ by a copper cadmium column and determined photometrically as $\mathrm{NO}_{2}^{-}$(Grasshoff, 1983). Sulfide was measured photometrically by the modified methylene blue method (Fonselius, 1983).

In the sediment samples $\mathrm{O}_{2}$ and $\mathrm{S}^{2-}$ concentrations and $\mathrm{pH}$ were measured with microsensors only in the upper $3 \mathrm{~cm}$, whereas $\mathrm{NO}_{3}^{-}$and $\mathrm{NO}_{2}^{-}$were measured at all depths using an ion chromatograph (Sykam, Fürstenfeldbruck, Germany). Measurements of dissolved $\mathrm{O}_{2}$ were done with fiberoptic microsensors (type B2, tip diameter $<50 \mu \mathrm{m}$; PreSens, Regensburg, Germany) connected to an $\mathrm{O}_{2}$-meter (Microx TX2, PreSens). Dissolved $\mathrm{S}^{2-}$ was measured with a potentiometric $\mathrm{Ag} / \mathrm{Ag}_{2} \mathrm{~S}$ electrode (tip diameter of $140 \mu \mathrm{m}$; Revsbech et al., 1983) modified according to Cypionka (1986). The $\mathrm{S}^{2-}$-sensor was connected to a mV-meter (3403 True RMS Voltmeter, Hewlett Packard, Böblingen, Germany). An ion-selective $\mathrm{pH}$-minielectrode (tip diameter of $1 \mathrm{~mm}$; Toepffer Lab System PHM-146, Göppingen, Germany) was connected to a $\mathrm{pH}$-meter. The microsensors were mounted together on a computer-controlled motorized micromanipulator (Märzhäuser $\mathrm{GmbH}$, Wetzlar, Germany) and inserted stepwise into the sediment. Porewater for analyses of $\mathrm{NO}_{3}^{-}$ and $\mathrm{NO}_{2}^{-}$was obtained by centrifugation. Nitrate and $\mathrm{NO}_{2}^{-}$ were measured by ion chromatography (Sykam) at a wavelength of $220 \mathrm{~nm}$.

\section{Nucleic acid extraction from water and sediment sam- ples}

Nucleic acid extraction for all water samples from frozen filters was performed as described by Weinbauer et al. (2002). DNA and RNA were obtained by mechanical and chemical extraction using glass beads and sodium lauryl sarcosinatephenol. Prior to PCR, DNA extracts were purified from RNA by incubation with RNase I (Roche Diagnostics, Mannheim, Germany) for $30 \mathrm{~min}$ at $37^{\circ} \mathrm{C}$, and DNA concentrations were determined using a NanoDrop ND-1000 spectrophotometer (NanoDrop Technologies, Inc., Rockland, ME, USA).

From sediment samples $(0.5 \mathrm{~g})$, DNA was extracted by adding $0.5 \mathrm{~g}$ glass beads, $900 \mu \mathrm{l}$ extraction buffer (Kramer and Singleton, 1993) and $100 \mu \mathrm{l}$ acid-washed polyvinylpolypyrrolidone (PVPP; Sigma-Aldrich, Deisenhofen, Germany; Ogram et al., 1998). First, cells were lysed by freezing $\left(30 \mathrm{~min},-70^{\circ} \mathrm{C}\right)$ and thawing $\left(65^{\circ} \mathrm{C}, 5 \mathrm{~min}\right)$ with concurrent shaking of the suspension at $1000 \mathrm{rpm}$ (Thermomixer; Eppendorf, Hamburg, Germany). In addition, cells were disrupted by bead beating twice for $30 \mathrm{~s}$ at $5.5 \mathrm{~m} \mathrm{~s}^{-1}$ (Fastprep Celldisrupter; Bio101, Carlsbad, CA, USA) and centrifuged at $12000 \times \mathrm{g}$ at $4^{\circ} \mathrm{C}$ for $1 \mathrm{~min}$. With the supernatant two extraction steps were performed: (1) with phenolchloroform-isoamylalcohol [24:24:1, v/v/v (volume in volume in volume)] and (2) with chloroform-isoamylalcohol $(24: 1, \mathrm{v} / \mathrm{v})$. Afterwards the DNA was concentrated by ethanol precipitation ( 2 volumes of $96 \%$ ethanol, $1 / 10$ volume of sodium acetate, $30 \mathrm{~min}$ at $-70^{\circ} \mathrm{C}$ ) and centrifuged $\left(16000 \times \mathrm{g}, 15 \mathrm{~min}, 4^{\circ} \mathrm{C}\right)$. The pellet was suspended in $50 \mu \mathrm{l}$ sterile aqua bidest. Humic acids were removed with PVPP columns (Ogram et al., 1998; Mendum et al., 1998) and the QIAqick Purification Kit (Qiagen, Hilden, Germany).

\subsection{PCR amplification}

Amplification of nirS genes was done with the primer pair nirS1F and nirS6R (MWG Biotech, Ebersberg, Germany) as described by Braker et al. (1998). nirS was amplified in a total volume of $25 \mu \mathrm{l}$ containing $1 \mu \mathrm{l}$ of environmental DNA, $10 \mathrm{pmol}$ of each primer, $400 \mathrm{ng}$ BSA (Roche, Mannheim, Germany) $\mu 1^{-1}, 200 \mu \mathrm{M}$ each of desoxyribonucleoside triphosphate (Roche Applied Science, Mannheim, Germany) and 1.25 U Red AccuTaq DNA polymerase (Sigma, 
Taufkirchen, Germany). PCRs were performed in a 9700 thermal cycler (Perkin-Elmer Cetus, Norwalk, CT, USA) or in an iCycler iQ (Biorad Laboratories, Inc., Hercules, CA, USA) with conditions modified according to Braker et al. (2000) and Braker et al. (2001). “Touchdown"-PCR started at $57^{\circ} \mathrm{C}$ until it reached $52.5^{\circ} \mathrm{C}$ in the first ten cycles. Additional 25 cycles were performed at an annealing temperature of $55^{\circ} \mathrm{C}$. For water samples the same program was used except that 26 cycles were performed with an annealing temperature of $56^{\circ} \mathrm{C}$.

Aliquots $(100 \mu \mathrm{l})$ PCR products were loaded on $1.5 \%$ [w/v (weight/volume)] agarose gels (SeaKem ${ }^{\circledR}$ LE agarose; Cambrex Bio Sciende, Rockland, ME, USA) and separated by electrophoresis ( $120 \mathrm{~V}, 45 \mathrm{~min})$. Bands were visualised by UV excitation after staining with ethidium bromide $\left(0.5 \mathrm{mg} \mathrm{l}^{-1}\right)$. Bands of the expected size were excised from the gel and purified using the QIAquick gel extraction kit (Qiagen, Hilden, Germany).

3.2 Terminal restriction fragment length polymorphism (TRFLP) analysis for sediment and water samples

For T-RFLP analysis the primer nirS1F was $5^{\prime}$-end labelled with 6-carboxyfluorescein (MWG Biotech, Ebersberg, Germany). The purified PCR products were digested with $0.3 \mathrm{U}$ of the restriction enzyme $H h a \mathrm{I}\left[\mathrm{GCG}^{\prime} \mathrm{C}\right.$ ] at $37^{\circ} \mathrm{C}$ overnight according to the manufacturer's instructions (Promega, Madison, WI, USA). Digested products were cleaned with Autoseq G-50 columns (Amersham Biosciences, Chalfont St. Giles, UK) according to the manufacturer's instructions. Aliquots of the digest $(2 \mu \mathrm{l})$ were mixed with $12 \mu \mathrm{l}$ deionised formamide (Applera, Darmstadt, Germany) and $0.2 \mu 1$ of an internal DNA fragment length standard (X-Rhodamine MapMarker ${ }^{\circledR} 30-1000$ bp; BioVentures, Murfreesboro, TN, USA). Terminal restriction fragments (T-RFs) were separated with an automated DNA sequencer (ABI 310, Applied Biosystems, Darmstadt, Germany). The length of fluorescently labelled T-RFs was determined by comparison with the internal standard using GeneScan 3.71 software (Applied Biosystems). Theoretical T-RFs from Baltic Sea sediment clones were determined by in silico analysis using the ARB-integrated tool TRF-CUT (Ricke et al., 2005).

\subsection{Analysis of Terminal Restriction Fragments (T-RFs)}

Peaks $\geq 60$ units of fluorescence from different samples were normalized by an iterative standardization procedure (Dunbar et al., 2001). The relative abundance of T-RFs in percent was determined by calculating the ratio between the heights of a given peak and the normalized total peak height of each sample. Richness of each sample corresponds to the number of T-RFs. Commonly used diversity indices, namely Shannon diversity and Shannon evenness index, were calculated:
Shannon diversity index $\mathrm{H}$ :

$H=-\sum p_{i} \times \log _{2} p_{i}$

Shannon evenness index J:

$J=\frac{H}{H_{\max }}=\frac{\sum p_{i} \times \log _{2} p_{i}}{\sum \hat{p}_{i} \times \log _{2} \hat{p}_{i}}$

where $p_{i}$ is the proportion (relative abundance) of T-RF $i$ in the community and $\hat{p}_{i}$ is the equally distributed relative abundance.

\subsection{Cloning and sequencing}

Unlabelled PCR products $(50 \mathrm{ng})$ of the sediment sample from the upper three centimeters ( 0 to $5 \mathrm{~mm}, 5$ to $12 \mathrm{~mm}$, and 12 to $30 \mathrm{~mm}$ depth) were cloned using the TA Cloning Kit (Invitrogen, Paisley, UK) according to the manufacturer's instructions. Clones were screened for inserts of the proper size using vector specific primers (T7, M13). The inserts were sequenced as described previously by Avrahami et al. (2002).

\subsection{Phylogenetic analysis}

nirS clones were aligned to sequences from the EMBL database with the ARB fast aligner feature. Phylogenetic analyses were performed with ARB (http://www.arb-home. de). Trees were reconstructed with the distance matrix-based neighbour joining method (ARB) and the overall topology was confirmed by trees calculated with PROTPARS and PROTML (PHYLIP; Felsenstein, 1993). Whenever the clustering of a given group of sequences was supported by all three algorithms, these sequences were considered to be consistently grouped together and were designated as clusters (Cluster I to VII) and subclusters which were indicated by shaded squares and polygons in the tree.

Nucleotide sequences retrieved from the Bodden sediments have been deposited in the EMBL database under accession numbers AM238454 to AM238510.

\section{Results}

\subsection{Field measurements}

In the water column of the Gotland Deep oxygen $\left(\mathrm{O}_{2}\right)$ decreased rapidly below the halocline (at a depth of $70 \mathrm{~m}$ ) from $300 \mu \mathrm{M}$ in the oxic layers to low concentrations $(10-50 \mu \mathrm{M})$ down to a depth of $220 \mathrm{~m}$ (Fig. 2a). The suboxic zone is the biochemical transition zone between oxic layers and sulfidic deep waters with dissolved oxygen concentrations $<10 \mu \mathrm{M}$ (Kirkpatrick et al., 2006). Oxygen was below the detection limit $(1 \mu \mathrm{M})$ starting at a depth of $220 \mathrm{~m}$. Sulfide $\left(\mathrm{S}^{2-}\right)$ was detected below a depth of $225 \mathrm{~m}$, reaching its maximum of $3.2 \mu \mathrm{M}$ at $230 \mathrm{~m}$. Thus, the suboxic zone was located between water depths of 220 and $225 \mathrm{~m}$. While nitrate $\left(\mathrm{NO}_{3}^{-}\right)$ concentration was low in the oxic layers it increased below 

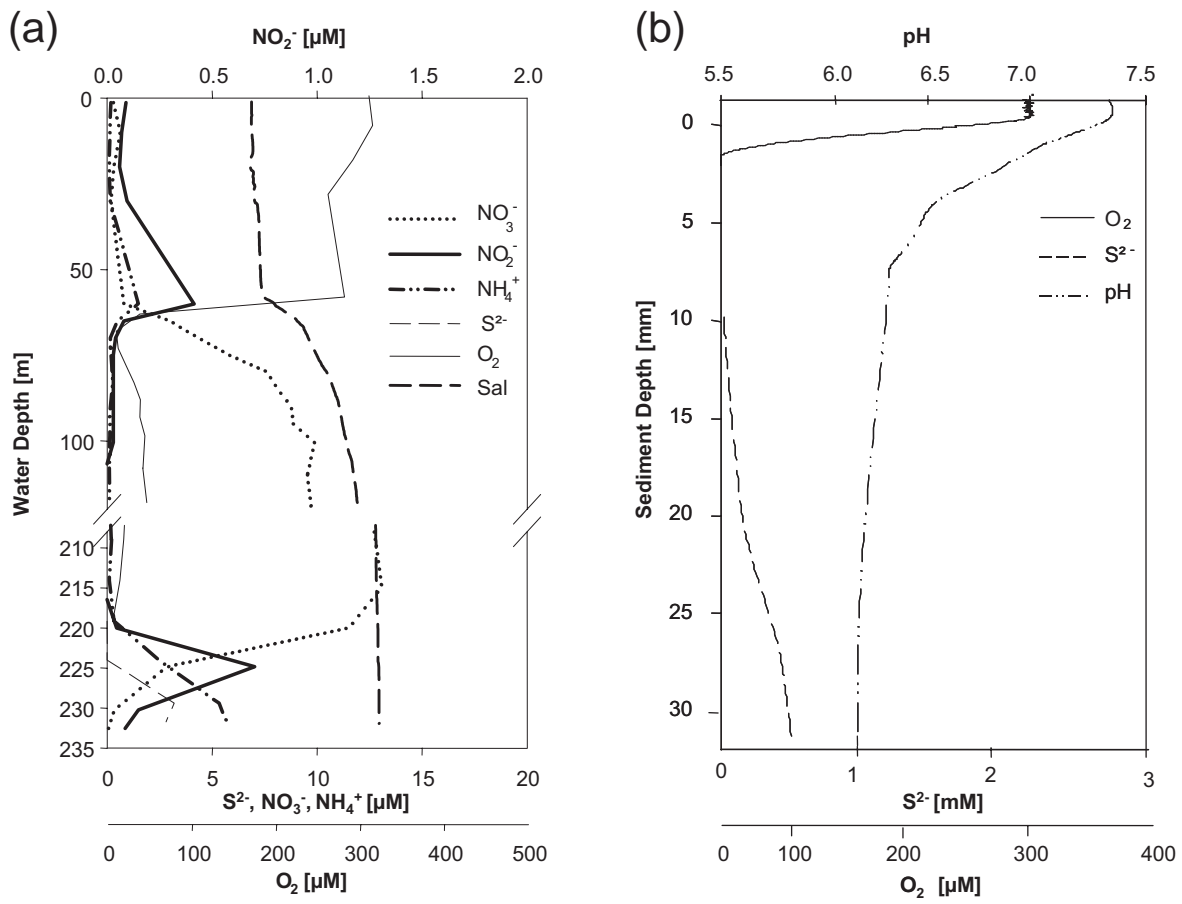

Fig. 2. Physical and chemical parameters of sampling sites in the Baltic Sea; (a) water column in the Gotland Deep, (b) coastal sediment in the Bodden.

the halocline and highest concentrations $(13 \mu \mathrm{M})$ were measured at a depth of $220 \mathrm{~m}$. Below this depth $\mathrm{NO}_{3}^{-}$concentration declined rapidly. Nitrite $\left(\mathrm{NO}_{2}^{-}\right)$concentration showed two peaks at depths of $55 \mathrm{~m}$ and $225 \mathrm{~m}$. In contrast, ammonium $\left(\mathrm{NH}_{4}^{+}\right)$was consistently low in the upper water column and increased below $225 \mathrm{~m}$.

In the coastal sediment sample $\mathrm{O}_{2}$ concentration decreased rapidly from $300 \mu \mathrm{M}$ to 0 within the top $2 \mathrm{~mm}$ (Fig. 2b). Nitrite was detected at two depths ( 0 to $2 \mathrm{~mm}$ and 2 to $5 \mathrm{~mm}$ depth) with concentrations of $0.25 \mu \mathrm{M}$ and $0.1 \mu \mathrm{M}$, respectively (data not shown) and was below the detection limit below $5 \mathrm{~mm}$ depth. Nitrate concentrations in the overlying water were $0.26 \mu \mathrm{M}$, whereas $\mathrm{NO}_{3}^{-}$in the sediment was below the detection limit in all layers. Sulfide started to accumulate in the sediment from a depth of $12 \mathrm{~mm}$ and reached its highest concentration $(0.5 \mathrm{mM})$ at a depth of $30 \mathrm{~mm}$.

\subsection{Denitrifier community profiles along biogeochemical gradients}

The communities of nirS-type denitrifiers from water samples (Gotland Deep) and coastal sediments (southern Baltic Sea) along the biogeochemical gradients at both sampling sites were analysed by T-RFLP of HhaI digested nirS amplicons. The restriction endonuclease HhaI showed the highest level of resolution compared to TaqI and MspI as indicated by the highest number of peaks observed (data not shown). In total, 22 different nirS T-RFs (terminal restriction frag- ments) were detected after hydrolysis with $\mathrm{HhaI}$ in samples from both sampling sites. T-RFLP patterns were highly reproducible for DNA extractions, PCR amplifications and TRFLP analyses of replicate samples from the same sediment cores (data not shown). Communities were also rather stable over time showing very similar nirS T-RFLP patterns compared to those from sediment samples taken one month earlier (June 2004). Representative T-RFLP profiles for the water column and sediment are shown in Fig. 3.

In the water column of the Gotland Deep, a total of 16 different nirS T-RFs were found. Diversity ( $\mathrm{H}$, Shannon diversity) and evenness (E, Shannon evenness) levels were the lowest $(\mathrm{H}=0.48 ; \mathrm{E}=0.44)$ in the upper oxygenated zone and the highest at depths from 100 to $200 \mathrm{~m}(\mathrm{H}, 1.74$ to 1.86 ; E, 0.84 to 0.90 ) (data not shown). Changes in the nirS-type denitrifier community structure at depths from 85 to $200 \mathrm{~m}$ were mainly based on changes in relative abundance of $\mathrm{T}$ RFs and few T-RFs of minor relative abundance appearing or disappearing. While the T-RF of $111 \mathrm{bp}$ dominated the denitrifier community profile in the water column at 70 to $85 \mathrm{~m}$, the relative abundance of the 36-bp T-RF increased with water depth and it became dominant at a depth of $200 \mathrm{~m}$. A strong shift in the community structure occurred from $200 \mathrm{~m}$ to $225 \mathrm{~m}$ depth. In contrast to the oxygenated zone, the 47-bp fragment was dominant in the sulfidic zone at 225 to $232.5 \mathrm{~m}$ depth (Fig. 3a). Some nirS T-RFs were specific for some layers of the water column at the Gotland Deep, i.e. those of 218, 295 and $380 \mathrm{bp}$. The majority of the T-RFs occurred at 


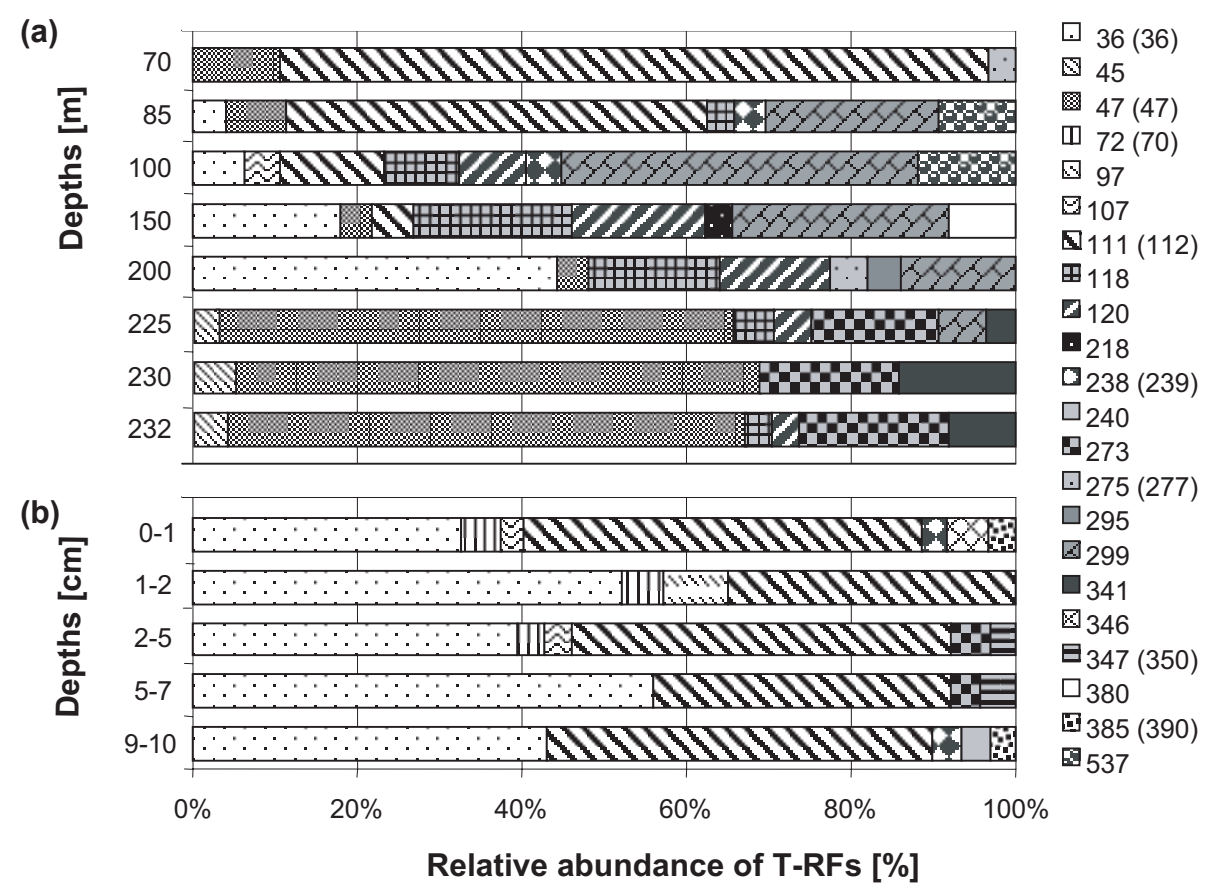

Fig. 3. Relative abundance of terminal restriction fragments of nirS amplicons. Numbers indicate the size of the fragment in base pairs after T-RFLP analysis, numbers in parentheses indicate size of the fragment after in silico analysis; (a) samples from the water column at the Gotland Deep; (b), samples from a sediment core taken in the Bodden.

several depths but were unique to the water column, i.e. TRFs of 45, 47, 118, 120, 275, 299, 341, and 537 bp. Specific T-RFs dominated some layers of the profiles of either 2003 or 2004. The main difference between profiles of both years is i) the reduced number of T-RFs in oxygenated water layers (up to 17 in 2003 and up to 8 in 2004) and in the sulfidic zone ii) the dominance of the 47-bp T-RF in 2004 instead of the 111-bp T-RF in 2003 as well as iii) the occurrence of the 273and 341-bp T-RFs in 2004 but disappearance of the 295-bp T-RF observed in this zone in 2003.

The occurrence and relative abundance of nirs T-RFs in the coastal sediment profiles was more homogenous $(\mathrm{H}, 0.95$ to 1.34 ; E, 0.66 to 0.76 ) than in the water column. However, the occurrence of the T-RFs of 346, 97 and $240 \mathrm{bp}$ was restricted to the sediment layers of 0 to 1,1 to 2 and 9 to $10 \mathrm{~cm}$ depth, respectively (Fig. 3b). In total, 11 different T-RFs were detected in five different sediment layers $(0$ to $10 \mathrm{~cm}$ ). The T-RFs of 36 and $111 \mathrm{bp}$, which occurred also in several depths in the water column, were predominant at all sediment depths. Many T-RFs were detected exclusively in the sediment samples, i.e. the 72-, 97-, 240-, 346-, 347-, and 385-bp T-RF. Several T-RFs i.e. those of 36, 107, 111, 238 , and 273 bp occurred both in samples from sediment and water column.
4.3 Phylogenetic affiliation of nirS sequences from marine habitats

A total of 57 nirS clones from environmental DNA, which were obtained from the coastal Baltic Sea sediment sample (BSS = Baltic Sea sediment), were included into a phylogenetic tree (Fig. 4). nirS sequences from the Gotland Deep station had been gathered in 2003 (Hannig et al., 2006) and were also considered (BS). Besides sequences from taxonomically described isolates, the overall tree also included all nirS sequences of unknown affiliation retrieved from other marine systems that were available in the database. These sequences were retrieved from the water column of the eastern South Pacific (ESP, Castro-Gonzalés et al., 2005), the Arabian Sea (ASW, Jayakumar et al., 2004), and the Northern Baltic Sea (CBBS, Tuomainen et al., 2003) and sediments of the Pacific Northwest (PNW, Braker et al., 2000) and the eastern tropical North Pacific (ETNP, Liu et al., 2003).

Phylogenetic analysis revealed seven major clusters of marine nirS sequences (marine Clusters I-VII). The overall topology was supported by the parsimony and maximum likelihood algorithm and clusters were defined if sequences were consistently grouped together despite low bootstrap values for some clusters (data not shown). Sequences from the Baltic Sea sediment (BSS cluster A to F) belonged to seven subclusters of nirS genes (Fig. 4). The majority of BSS sequences (29) belonged to BSS Cluster A to E and were placed in marine Cluster I. For these clones terminal 


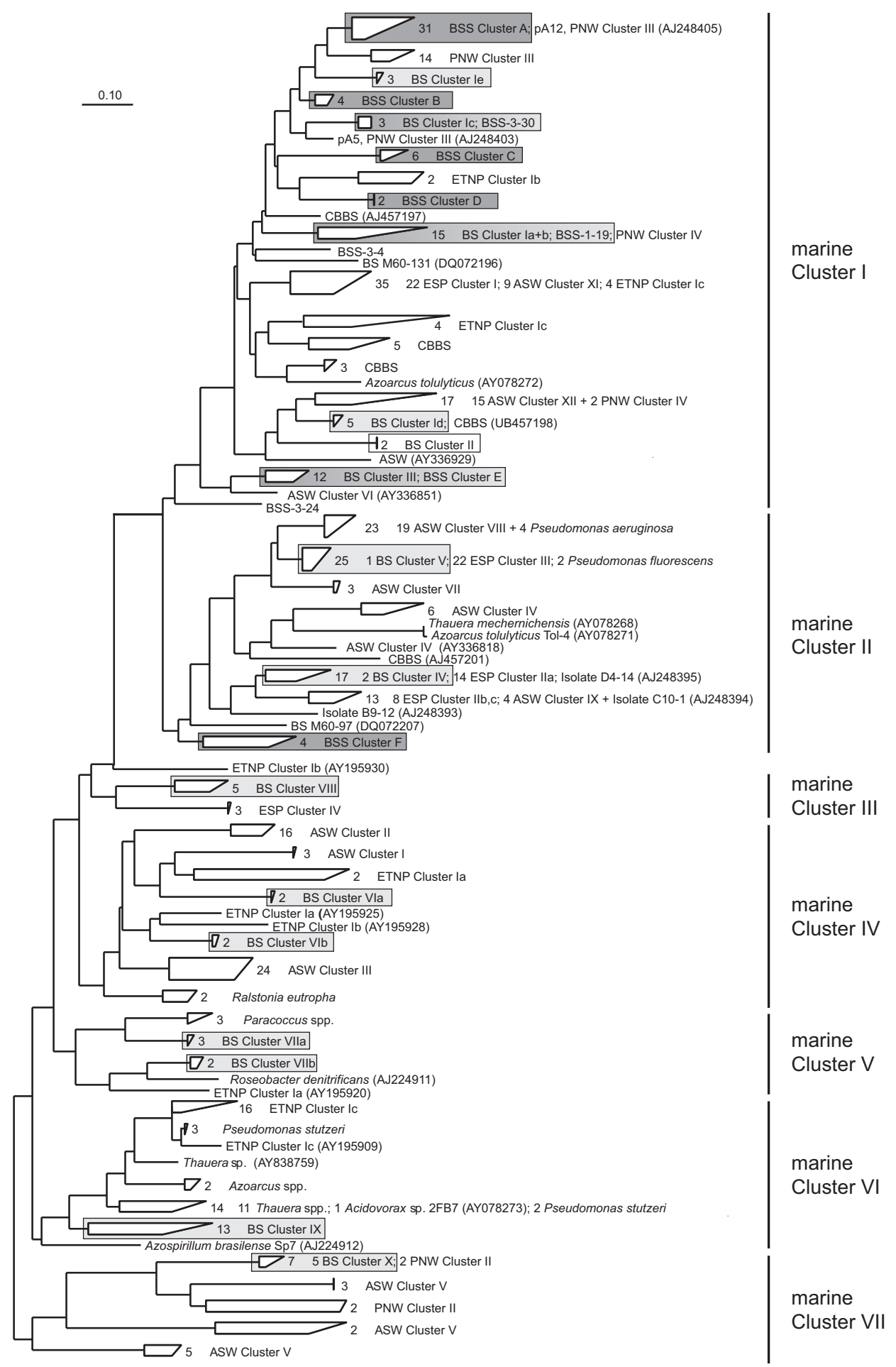

Fig. 4. Phylogenetic tree of nirS sequences from all marine habitats. Tree was calculated by the neighbour joining method based on an alignment of 166 amino acids. Roman numbers indicate marine nirS sequence clusters. nirS sequences from sediment samples from the Baltic Sea were labelled with BSS. Clones were labelled with numbers to indicate from which depth of the sediment sequences were retrieved ( 1,0 to $5 \mathrm{~mm} ; 2,5$ to $12 \mathrm{~mm} ; 3,12$ to $30 \mathrm{~mm}$ ) and a second number for the respective clone. nir $S$ clusters from Baltic Sea sediments were labelled with A to F. The number after the polygon indicates the number of clones of a given cluster. ASW, Arabian Sea water column; BS, Baltic Sea water column; CBBS, cyanobacterial bloom Baltic Sea; ESP, eastern South Pacific sediment; ETNP, eastern tropical North Pacific sediment; PNW, Pacific Northwest sediment. 


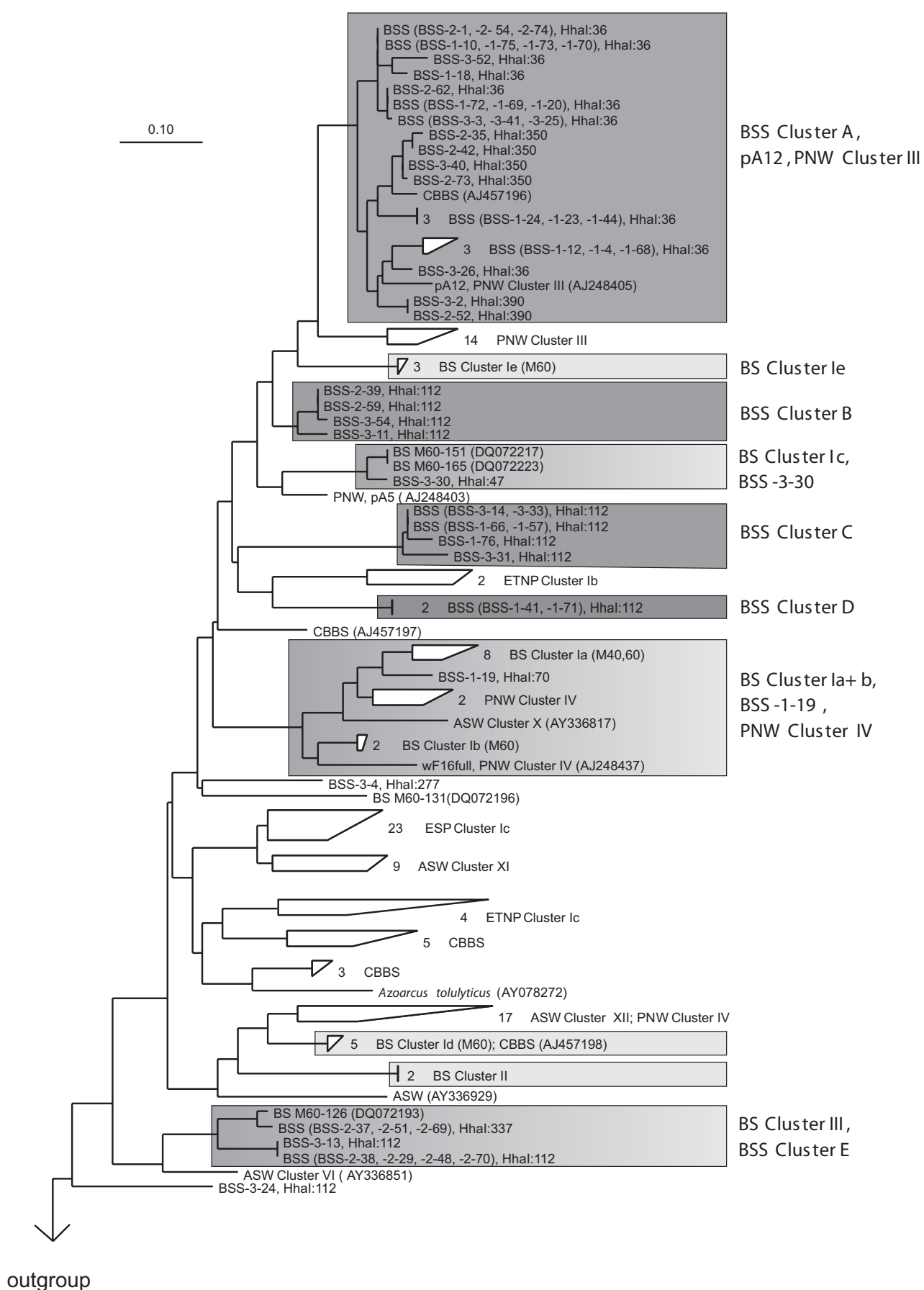

Fig. 5. Phylogenetic tree of nirS sequences clustering in marine Cluster I. nirS sequences from sediment samples from the Baltic Sea were labelled with BSS. Clones were labelled with numbers to indicate from which depth of the sediment sequences were retrieved (1, 0 to $5 \mathrm{~mm}$; 2,5 to $12 \mathrm{~mm} ; 3,12$ to $30 \mathrm{~mm}$ ) and a second number for the respective clone. nirS clusters from Baltic Sea sediments were labelled with A to $\mathrm{F}$. The number after the polygon indicates the number of clones of a given cluster. The number after the restriction enzyme name (HhaI) indicates the size of the terminal restriction fragment. ASW, Arabian Sea water column; BS, Baltic Sea water column; CBBS, cyanobacterial bloom Baltic Sea; ESP, eastern South Pacific sediment; ETNP, eastern tropical North Pacific sediment; PNW, Pacific Northwest sediment. 
restriction fragments of $36,47,70,112,277,350$, and $390 \mathrm{bp}$ were found by in silico analysis (Fig. 5). These T-RFs corresponded to the major fraction of T-RFs in the sediment profiles. BSS Cluster A sequences were dominated by the 36-bp T-RF, but T-RFs of 350 and $390 \mathrm{bp}$ also occurred for two subgroups. BSS Cluster B, C, and D sequences showed a common T-RF of $112 \mathrm{bp}$ that also occurred in BSS Cluster E. Within Cluster E a second T-RF of $337 \mathrm{bp}$ was found. Unique T-RFs of 47, 70, and $277 \mathrm{bp}$ correspond to single clones found in Cluster I. Cluster I also included nirS genes from marine sediments (PNW Cluster III and IV; ETNP Cluster Ib and Ic) and water column (ASW Cluster XI and XII; ESP Cluster I) as well as sequences from the water column (BS) and from a cyanobacterial bloom (CBBS) from the Baltic Sea. An in-depth analysis of Cluster I-sequences showed that nir $S$ sequences from the oxic ( 0 to $5 \mathrm{~mm}$ depth, top $2 \mathrm{~mm}$ oxic), suboxic (5 to $12 \mathrm{~mm}$ depth), and sulfidic zone (12 to $30 \mathrm{~mm}$ depth) of the Baltic Sea sediment were not clustered according to the prevalent environmental conditions in these zones (Fig. 5). In contrast, sequences from all three zones were found distributed in several shared subclusters within Cluster I. The majority of Cluster I nirS sequences were placed in subclusters according to the location from which they originated. However, one subcluster was dominated by sequences from the Bodden sediment, but contained also nirS from a cyanobacterial mat within the Baltic Sea, and a sequence from Puget Sound (PNW). The most closely related sequences to this subcluster were $14 \mathrm{nirS}$ sequences from Puget Sound sediment (PNW) which formed a sister group to the first subcluster dominated by sequences from the Baltic Sea sediment. Another subcluster included nirS from the Baltic Sea water column and sediment, the PNW, and one from the ASW.

In marine sequence Cluster II, BSS Cluster F grouped together albeit as a distinct subcluster with sequences from several clusters from the ASW (Cluster IV, VII, VIII, IX), the ESP (Cluster IIa, IIb, IIc, III), and the Baltic Sea (BS Cluster IV, V, one sequence each from the BS and the CBBS). For the four BSS clones within Cluster II T-RFs of 239 (2), 277 (1), and 511 (1) bp were found (data not shown). Marine Cluster II also comprised sequences from denitrifying isolates (Pseudomonas spp., Thauera mechernichensis, Azoarcus tolulyticus and marine isolates affiliated with Marinobacter spp. and Halomonas variabilis).

Marine sequence clusters III, IV, V, VI, and VII harbored no sequences from the Baltic Sea sediment but sequences from the water column of the Baltic Sea and from the other marine habitats. Within these clusters, subclusters were identified that were located on separate branches within the tree and harbored sequences from either water column or sediment habitats. Cluster III contained sequences from the Baltic Sea (Cluster VIII) and the ESP (Cluster IV). Cluster IV contained nirS from the ASW (Cluster I, II and III), the ETNP (Cluster Ia and Ib), and the Baltic Sea (Cluster VIa and $\mathrm{VIb}$ ) and nirS from Ralstonia eutropha. Marine nirS sequences from the Baltic Sea (Cluster VIIa and VIIb) and the ETNP (Cluster Ia) were related to those from Paracoccus denitrificans and Roseobacter denitrificans. Most sequences found in Cluster VI originate from cultured denitrifiers e.g. Thauera spp., Azoarcus spp and Pseudomonas stutzeri and related marine isolates. Sequences from the ETNP (Cluster Ic) and the Baltic Sea (BS Cluster IX) were also grouped in this cluster. Marine Cluster VII consisted exclusively of nirS genes from clones from the Baltic Sea (Cluster X), the ASW (Cluster V) and the PNW (Cluster II) with seven nirS sequences from the water column of the Baltic Sea and the sediment of the PNW forming a common subcluster.

\section{Discussion}

A number of studies to date have explored denitrifier communities from marine habitats but they all were from distinct geographic locations. Originating either from the water column or sediment, they were separated by large geographic distances of thousands of kilometres, e.g. from the Pacific Northwest (Braker et al., 2000), the eastern tropical North Pacific (Liu et al., 2003), the eastern South Pacific (CastroGonzalés et al., 2005) or even by continents as for the locations in the Pacific, in the Arabian Sea (Jayakumar et al., 2004) and in the Baltic Sea (Hannig et al., 2006). Thus, these sites were presumably influenced by distinct environmental conditions.

In this study nirS-type denitrifier communities were explored from water column (Gotland Deep) and sediment samples (Rassower Strom, Bodden) of the Baltic Sea (Fig. 1). The two sites are $550 \mathrm{~km}$ apart but belong to the same water body. The difference in salinity between the two sites is also quite small (7-9 at the Bodden, 7-13 at the Gotland Deep). Common to both habitats are the gradients of biogeochemical parameters with a strong oxic-anoxic interface (Fig. 2) that never co-occur in both water column and sediment at the same site. Water masses are exchanged horizontally between coastal areas and the central Baltic (minimal flow velocity: $<1 \mathrm{~cm} \mathrm{~s}^{-1}$; Maagard and Rheinheimer, 1974) and vertically between water column and sediment. Despite the fact that the Baltic proper may represent a closed circulation cell (Voss et al., 2005) approximately once in a decade an inflow of North Sea water occurs. This happened in 2003 when a massive inflow of $200 \mathrm{~km}^{3}$ deep oxygenated North Sea water with a high salinity occurred from spring till summer (Feistel et al., $2003 a, b)$. In the summer of 2003, this resulted in successive changes in bottom water temperature and salinity along a transect from the Darss Sill area (in proximity to our sampling site at the Rassower Strom) via the Bornholm Deep to the Gotland Basin (Feistel et al., 2004). This suggests that not only water masses are exchanged but also microbial communities. Furthermore, both locations were characterized by different anthropogenic influence (Hübel et al., 1998). In contrast to the Baltic proper, coastal areas are affected by 
high riverine nitrogen inputs which lead to high denitrification N-losses (Voss et al., 2005), but for the coastal area included in our study summertime denitrification rates were low (Dahlke, 1990).

Oxygenated surface water in the Gotland Deep is separated by a stable halocline from deeper waters at 60 to $70 \mathrm{~m}$. This halocline prevents vertical mixing and results in longlasting suboxic zones and sulfidic/anoxic conditions in the near bottom water. However, recently even deep layers of the Gotland Deep were provided with oxygen $\left(\mathrm{O}_{2}\right)$ because of several inflows of dense North Sea from summer of 2002 to the summer of 2003 (Feistel et al., 2003a, b, 2004). After the disappearance of sulfide $\left(\mathrm{S}^{2-}\right)$ in 2003, a newly developed redoxcline appeared during 2004 at a depth of 225 to $230 \mathrm{~m}$ where the concentration of nitrate $\left(\mathrm{NO}_{3}^{-}\right)$decreased and that of $\mathrm{S}^{2-}$ increased towards the sediment. In contrast, the sediment samples of the Bodden were anoxic below the first $2 \mathrm{~mm}$. Sulfide appeared below a depth of $7 \mathrm{~mm}$ and accumulated at concentrations two orders of magnitude higher than in the water column. The accumulation of $\mathrm{S}^{2-}$ in the anoxic layers of both habitats suggests active sulfate reducing microbial communities.

5.1 Denitrifier communities along vertical chemical gradients in the water column and sediment

Terminal restriction fragment length polymorphism ( $\mathrm{T}$ RFLP) of nirS amplicons has been successfully used as a fingerprinting method to analyse denitrifier community structure (Braker et al., 2001; Castro-González et al., 2005; Hannig et al., 2006). We focused on nirS as a functional marker gene to detect denitrifiers since amplification of nirK encoding the second, copper-containing type of nitrite reductase failed for the marine samples explored in this study when specific primers developed by Braker et al. (2000) were used. Whether this reflects a primer bias or it is of ecological relevance remains unknown. In any case, the majority of studies on marine denitrifier communities had focused on nirS, thus making comparisons between the Baltic Sea and other marine systems based on this gene more reasonable.

T-RFLP analysis of nirS genes demonstrated partial overlaps between water and sediment communities but also revealed unexpected dissimilarities between communities despite comparable physico-chemical gradients in the water column and the sediment. While community profiles from the water column showed strong vertical shifts, particularly from the oxygenated through the low oxygen zone to sulfidic conditions, this was not the case for the sediment community profiles (Fig. 3). Minor changes in nirS-type denitrifier, bacteria and archaea community composition despite strong small-scale biogeochemical gradients were also observed with depth in a sediment core collected from the Puget Sound, Washington, USA (Braker et al., 2001). Sequence analysis of clones from the Bodden sediment core showed a comparably uniform community composition for the oxic, suboxic, and anoxic zones as the sequences grouped in common subclusters (BSS Cluster A to F). This also agrees with the nirS-sequences retrieved from three layers of the Puget Sound sediment core clustering in a common Puget Sound cluster (Braker et al., 2000). In the shallow waters of the Bodden, turbulence causes greater input of $\mathrm{O}_{2}$ into the upper sediment. Furthermore, the sediment stratification and the distribution of porewater solutes (e.g. $\mathrm{O}_{2}$ ) can be influenced by bioturbation through feeding and locomotion activity of marine invertebrates. Thereby $\mathrm{O}_{2}$ is inserted into the anoxic sediment layers (Forster et al., 1995). After a bioturbation event, the observed chemical gradients, which are the result of differential metabolic activities of microbial communities in the sediment, are re-established much faster than gradients in bacterial community structure.

In contrast, the water column zonation of denitrifier communities is probably more stable as each stratified layer extends across a range of several meters. The highest level of diversity of cultivable denitrifying heterotrophic bacteria was found at the suboxic-sulfidic interface in the water column of the Gotland Deep (Brettar et al., 2001). This was not visible by T-RFLP analysis, which revealed approximately similar numbers of T-RFs in the different layers. With a concurrent accumulation of $\mathrm{NO}_{3}^{-}$in the water column the community structure shifted with depth from 85 to $200 \mathrm{~m}$ depth (Figs. 2 and 3). However, the most pronounced shift occurred with the transition to the sulfidic zone. At the suboxicsulfidic interface, where $\mathrm{NO}_{3}^{-}$and $\mathrm{S}^{2-}$ frequently co-occur, autotrophic denitrification has been demonstrated (Brettar and Rheinheimer, 1991; Hannig et al., 2007). Our community profiles, e.g. the dominance of the 47-bp T-RF and the appearance of the 273-bp T-RF, indicate that specific planktonic denitrifiers are adapted to thrive under sulfidic conditions. Similar shifts in denitrifier community composition and the appearance of abundant T-RFs specific for the sulfidic zone were recently observed for the water column at one station in the vicinity of the Gotland Deep in August and October 2003 (Hannig et al., 2006). However, these T-RFs were not identical to those dominating the sulfidic zone one year earlier (2003). This observation presumably indicates a shift in community composition despite similar biochemical gradients in the water column within one year after the inflow of North Sea water.

Two dominant T-RFs (36 and $111 \mathrm{bp}$ ) were found in all layers of the sediment and were identical to the two T-RFs dominating the oxygenated zone (111-bp T-RF) down to the top of the suboxic zone (36-bp T-RF). The 273-bp T-RF seems to be indicative of denitrifier communities in sulfidic environments as it was also found in the respective zones in the water column. This suggests a more general occurrence of organisms capable of autotrophic nitrate reduction and sulfide oxidation, such as Thiomicrospira denitrificanslike bacteria. These epsilon-proteobacteria were identified as some of the dominant denitrifiers at the suboxic-sulfidic interface of the water column at the Gotland Deep (Labrenz et 
al., 2005; Brettar et al., 2006). However, according to our latest phylogenetic analysis nirS from Thiomicrospira denitrificans is not closely related to any other known nirS sequence and consequently also not to any of our clones. It should be noted that nirS is not a phylogenetic marker and that these genes are possibly transferred between phylogenetically unrelated strains by horizontal gene transfer. Therefore, it is difficult if not impossible to infer a phylogenetic relationship between Thiomicrospira denitrificans and other denitrifiers based exclusively on the analysis of their nirS genes.

\subsection{Phylogeny of nirS sequences from marine environ-} ments

Community profiles were studied by T-RFLP based on cleavage of nirS PCR products using a single restriction enzyme. This approach is suitable to analyse shifts in denitrifier communities along environmental gradients but may be limited due to the occurrence of identical T-RFs that correspond to sequences from different clusters within the nirS tree. This was indeed the case for sequences showing a common 112bp T-RF that belonged to BSS Cluster B, C, D, and E. However, other clusters harbored sequences with different T-RFs such as those with the 36- and 350-bp T-RF in Cluster A and T-RFs of 112 and $337 \mathrm{bp}$ in Cluster E. A better resolution can be achieved by the use of different restriction enzymes (Osborn et al., 2006) or phylogenetic analysis of sequences from clones.

The phylogenetic tree (Fig. 4), containing most of the published nirS sequences from marine environments, shows that only few nirS sequences are similar to those from denitrifying isolates (e.g. in marine Cluster II: ASW Cluster VIII, 95.6 to $100 \%$ identical to Pseudomonas aeruginosa; ESP Cluster III, 93.7 to $96.9 \%$ identical to Pseudomonas fluorescens). Whether these genes were indeed derived from Pseudomonas spp. is unknown because a distribution of denitrification genes via horizontal gene transfer among phylogenetically unrelated organisms is possible (Etchebehere and Tiedje, 2005). Therefore our results confirm that the marine environment is strongly dominated by diverse and novel nirS-type denitrifiers that are presumably not cultured yet.

Most environmental nirS sequences grouped in separate subclusters according to the site from which they were obtained (Fig. 4). The habitat, water column or sediment, obviously has a strong impact on denitrifier community composition. Nonetheless, there were also some interesting overlaps of denitrifier communities. Only within marine Cluster I, water column and sediment sequences grouped within the same subclusters (Fig. 5). Three of them harboured sequences from both sites of the Baltic Sea, covering sequences from all sediment depths but only from the oxygenated zone of the water column. This is not surprising since horizontal currents lead to constant water exchange within the upper layers of the Baltic. Further, within the shallow coastal areas a continuous exchange occurs between sediments and overlaying water.

Interestingly, a group of sequences from all depths of the Bodden sediment, grouping in marine Cluster I, were closely related to $\mathrm{nirS}$ genes found in a sediment core from the Puget Sound, WA. Sediments from both locations share similar features, i.e. denitrifier communities were stable with depth within the core, and electron acceptors $\mathrm{O}_{2}$ and $\mathrm{NO}_{3}^{-}$were consumed within the first few millimetres. However, no $\mathrm{S}^{2-}$ was detected at these depths in the core from Puget Sound (A. H. Devol, personal communication). Only little nirS sequence overlap among denitrifier communities was observed for sediments of the Puget Sound and offshore Washington coast (Braker et al., 2000). This was attributed to separation of microbial communities by large distances and to the degree of degradation of the organic matter reaching the sediment. Distinct sediment characteristics at large geographic distances, bottom topography at the metre scale and small scale $(\mathrm{cm})$ differences due to meio- and macrofaunal abundance were shown to impact marine sediment denitrifier communities to an extent ranking in the order $\mathrm{km}>\mathrm{m}>\mathrm{cm}$ (Scala and Kerkhof., 2000). However, we conclude that in sediments with comparable environmental conditions similar nirS-type denitrifier communities can develop despite large geographic distances. Physico-chemical parameters (e.g. $\mathrm{O}_{2}, \mathrm{NO}_{3}^{-}, \mathrm{NO}_{2}^{-}, \mathrm{NH}_{4}^{+}, \mathrm{PO}_{4}$, dissolved organic carbon, salinity) were shown to impact the composition and distribution of denitrifier communities (Liu et al., 2003; TaroncherOldenburg et al., 2003; Jayakumar et al., 2004; CastroGonzalés et al., 2005; Hannig et al., 2006). The nirS tree (Fig. 4) reveals that similar environmental conditions (with respect to $\mathrm{O}_{2}, \mathrm{NO}_{3}^{-}$, and $\mathrm{NO}_{2}^{-}$) in the water column of the distantly located ESP and the ASW also seem to have triggered the development of similar communities (ESP Cluster I and ASW Cluster XI, within marine Cluster I).

In conclusion, from the data base obtained so far it seems that distinct marine nirS-type denitrifier communities occupy different ecological niches which are defined by the habitat, water column or sediment, shaped by the prevalent environmental conditions, and can be isolated by large geographic distances. nirS subgroups are mostly site-specific but overlap if communities are impacted by similar environmental conditions. It is evident that denitrifiers are widespread, occurring also in habitats in which denitrification does not appear to occur in the bulk of the water column, e.g. due to lack of $\mathrm{NO}_{3}^{-}$ or presence of $\mathrm{O}_{2}$. However, all the DNA-based studies indicate the genetic potential for denitrification but they do not reveal whether these communities are actively denitrifying or not. Most cultured denitrifiers grow preferentially as heterotrophs in the presence of $\mathrm{O}_{2}$ but not as denitrifiers if possible. Thus, the ability to denitrify is probably not the factor that exclusively selects for subgroups of denitrifier communities in the different habitats. We assume that the subclusters of closely related nirS sequences belong to the same bacterial 
taxa. These are adapted to a specific niche due to their set of genetic and phenotypic characters among which the capacity for denitrification is only one. Nothing is known yet about the phylogenetic affiliation and ecophysiology of the organisms from which the novel nirS sequence types from marine habitats were retrieved. Future studies should therefore aim to combine different approaches in order to gain further insights in the adaptation and regulation of denitrifying communities; for example, species-specific activity measurements and phylogenetic analysis, metagenomic libraries and cultivation-based studies.

\section{Authors' comment}

After publication of this work a manuscript was published on nirS and nirK-type denitrifier communities in the Black Sea (Oakley et al., Environ. Microbiol., 2006). Their data were not incorporated into our data set.

Recently, Thiomicrospira denitrificans was reclassified as Sulfurimonas paralvinellae (Takai, K., Suzuki, M., Nakagawa, S., Miyazaki, M., Suzuki, Y., Inagaki, F., and Horikoshi, K.: Sulfurimonas paralvinellae sp. nov., a novel mesophilic, hydrogen- and sulfur-oxidizing chemolithoautotroph within the Epsilonproteobacteria isolated from a deep-sea hydrothermal vent polychaete nest, reclassification of Thiomicrospira denitrificans as Sulfurimonas denitrificans comb. nov. and emended description of the genus Sulfurimonas, Int. J. Syst. Evol. Micr., 56, 1725-1733, 2006).

Acknowledgements. The authors thank the officers, the crew and the scientists of the R/V "A. v. Humboldt" and "Prof. Gessner" for assistance with sampling collection. M. Labrenz and H. Brockmüller are thanked for the help during sampling; S. Pfeiffer, B. Hambach, and S. Kolbatsch-Weremtschuk did the nutrient measurements. K. Bünger, S. Fleissner, and K. Schwarz are acknowledged for technical assistance. The research was founded by grants from the University of Greifswald, the Baltic Sea Research Institute Warnemünde and the Max-Planck-Society.

Edited by: S. W. A. Naqvi

\section{References}

Andrén, E., Andrén, T., and Kunzendorf, H.: Holocene history of the Baltic Sea as a background for assessing records of human impact in the sediments of the Gotland Basin, The Holocene, 10, 687-702, 2000.

Avrahami, S., Conrad, R., and Braker, G.: Effect of soil ammonium concentration on $\mathrm{N}_{2} \mathrm{O}$ release and on the community structure of ammonia oxidizers and denitrifiers, Appl. Environ. Microbiol., 68, 5685-5692, 2002.

Black, H. J., Dainat, M., Köster, M., and Meyer-Reil, L.-A.: A multiple corer for taking virtually undisturbed samples from shallow water sediments, Estuar. Coast. Shelf S., 54, 45-50, 2002.

Braker, G., Ayala-del-Río, H. L., Devol, A. H., Fesefeldt, A., and Tiedje, J. M.: Community structure of denitrifiers, bac- teria, and archaea along redox gradients in Pacific Northwest marine sediments by terminal restriction fragment length polymorphism analysis of amplified nitrite reductase (nirS) and 16S rRNA genes, Appl. Environ. Microbiol., 67, 1893-1901, 2001.

Braker, G., Fesefeldt, A., and Witzel, K.-P: Development of PCR primer systems for amplification of nitrite reductase genes (nirK and nirS) to detect denitrifying bacteria in environmental samples, Appl. Environ. Microbiol., 64, 3769-3775, 1998.

Braker, G., Zhou, J., Wu, L., Devol, A. H., and Tiedje, J. M.: Nitrite reductase genes (nirK and nirS) as functional markers to investigate diversity of denitrifying bacteria in Pacific Northwest marine sediment communities, Appl. Environ. Microbiol., 66, 2096-2104, 2000.

Brettar, I. and Höfle, M. G.: Nitrous oxide producing heterotrophic bacteria from the water column of the central Baltic: Abundance and molecular identification, Mar. Ecol. Prog. Ser., 94, 253-265, 1993.

Brettar, I., Labrenz, M., Flavier, S., Bötel, J., Kuosa, H., Christen, R., and Höfle, M. G.: Identification of a Thiomicrospira denitrificans-like epsilonproteobacterium as a catalyst for autotrophic denitrification in the central Baltic Sea, Appl. Environ. Microbiol., 72, 1364-1372, 2006.

Brettar, I., Moore, E. R. B., and Höfle, M. G.: Phylogeny and abundance of novel denitrifying bacteria isolated from the water column of the central Baltic Sea, Microb. Ecol., 42, 295-305, 2001.

Brettar, I. and Rheinheimer, G.: Denitrification in the central Baltic: Evidence for $\mathrm{H}_{2} \mathrm{~S}$-oxidation as motor of denitrification at the oxic-anoxic interface, Mar. Ecol. Prog. Ser., 77, 157-169, 1991.

Castro-González, M., Braker, G., Farías, L., and Ulloa, O.: Communities of nirS-type denitrifiers in the water column of the oxygen minimum zone in the eastern South Pacific, Environ. Microbiol., 7, 1298-1306, 2005.

Cypionka, H.: Sulfide-controlled continuous culture of sulfatereducing bacteria, J. Microbiol Meth., 5, 1-9, 1986.

Dahlke, S.: Denitrification in sediments of north rugian estuaries, preliminary communication, Limnologica, 20, 145-148, 1990.

Dunbar, J., Ticknor, L. O., and Kuske, C. R.: Phylogenetic specificity and reproducibility and new method for analysis of terminal restriction fragment profiles of 16S rRNA genes from bacterial communities, Appl. Environ. Microbiol., 67, 190-197, 2001.

Etchebehere, C. and Tiedje, J. M.: Presence of two different active nirS nitrite reductase genes in a denitrifying Thauera sp. from a high-nitrate-removal-rate reactor, Appl Environ Microbiol., 71, 5642-5645, 2005.

Feistel, R., Nausch, G., Heene, T., Piechura, J., and Hagen, E.: Evidence for a warm water inflow into the Baltic proper in summer 2003, Oceanologia, 46, 581-598, 2004.

Feistel, R., Nausch, G., Matthäus, W., and Hagen, E.: Temporal and spatial evolution of the Baltic deep water renewal in spring 2003, Oceanologia, 45, 623-642, 2003a.

Feistel, R., Nausch, G., Mohrholz, V., Łysiak-Pastuszak, E., Seifert, T., Matthäus, W., Krüger, S., and Hansen, I. S.: Warm waters of summer 2002 in the deep Baltic proper, Oceanologia, 45, 571592, $2003 \mathrm{~b}$.

Felsenstein, J.: PHYLIP: Phylogeny interference package (Ver. 3.5c). Seattle, WA, USA: Department of Genetics, University of Washington, 1993.

Fonselius, S.: Determination of hydrogen sulfide, in: Methods of seawater analysis, edited by: Grasshoff, K., Ehrhardt, M., and 
Kremling, K., pp. 73-80, Verlag Chemie, Weisheim, 1983.

Forster, S., Graf, G., Kitlar, J., and Powilleit, M.: Effects of bioturbation in oxic and hypoxic conditions: A microcosm experiment with a North Sea sediment community, Mar. Ecol. Prog. Ser., 116, 153-161, 1995.

Grasshoff, K.: Determination of oxygen, thiosulphate, nitrite and nitrate, in: Methods of seawater analysis, edited by: Grasshoff, K., Ehrhardt, M., and Kremling, K., pp. 61-72, 81-84, 139-142, 143-150, Verlag Chemie, Weinheim, 1983.

Hannig, M., Braker, G., Dippner, J. W., and Jürgens, K.: Linking denitrifier community structure and prevalent biogeochemical parameters in the pelagial of the central Baltic Proper (Baltic Sea), FEMS Microbiol. Ecol., 57, 260-271, 2006.

Hannig, M., Lavik, G., Kuypers, M. M. M., Woebken, D., MartensHabbena, W., and Jürgens, K.: Shift from denitrification to anammox after inflow events in the central Baltic Sea, Limnol. Oceanogr., 52, in press, 2007.

Höfle, M. G. and Brettar, I.: Genotyping of heterotrophic bacteria from the central Baltic Sea by use of low-molecular-weight RNA profiles, Appl. Environ. Microbiol., 62, 1383-1390, 1996.

Höfle, M. G., Flavier, S., Christen, R., Bötel, J., Labrenz, M., and Brettar, I.: Retrieval of nearly complete $16 \mathrm{~S}$ rRNA gene sequences from environmental DNA following 16S rRNA-based community fingerprinting, Environ. Microbiol., 7, 670-675, 2005.

Hübel, H., Wolff, C., and Meyer-Reil, L.-A.: Salinity, inorganic nutrients, and primary production in a shallow coastal inlet in the southern Baltic Sea (Nordrügensche Bodden) results from long-term observations (1960-1989), Internat. Rev. Hydrobiol., 83, 479-499, 1998.

Jayakumar, D. A., Francis, C. A., Naqvi, S. W. A., and Ward, B. B.: Diversity of nitrite reductase genes (nirS) in the denitrifying water column of the coastal Arabian Sea, Aquat. Microbiol. Ecol., 34, 69-78, 2004.

Kirkpatrick, J., Oakley, B., Fuchsman, C., Srinivasan, S., Staley, J. T., and Murray, J. W.: Diversity and distribution of Planctomycetes and related bacteria in the suboxic zone of the Black Sea. Appl. Environ. Microbiol., 72, 3079-3083, 2006.

Koroleff, F.: Determination of ammonia, in: Methods of seawater analysis, edited by: Grasshoff, K., Ehrhardt, M., and Kremling, K., pp. 150-157, Verlag Chemie, Weinheim, 1983.

Kotilainen, A. T., Hämäläinen, J. M. S., and Winterhalter, B.: Reconstructing a continuous Holocene composite sedimentary record for the eastern Gotland Deep, Baltic Sea, Boreal Environ. Res., 7, 1-12, 2002.

Kramer, J. and Singleton, F.: Measurement of rRNA variation in natural communities of microorganisms on the south-eastern U.S. Continental Shelf, Appl. Environ. Microbiol., 59, 24302436, 1993.

Labrenz, M., Brettar, I., Christen, R., Flavier, S., Bötel, J., and Höfle, M. G: Development and application of real-time PCR approach for quantification of uncultured bacteria in the central Baltic Sea, Appl. Environ. Microbiol., 70, 4971-4979, 2004.

Labrenz, M., Jost, G., Pohl, C., Beckmann, S., Martens-Habbena, W., and Jürgens, K.: Impact of different in vitro electron donor/acceptor conditions on potential chemolithoautotrophic communities from marine pelagic redoxcline, Appl. Environ. Microbiol., 71, 6664-6672, 2005.

Liu, X., Tiquia, S. M., Holguin, G., Wu, L., Nold, S. C., Devol, A.
H., Luo, K., Palumbo, A. V., Tiedje, J. M., and Zhou, J.: Molecular diversity of denitrifying genes in continental marine sediment within the oxygen-deficient zone off the Pacific coast of Mexico, Appl. Environ. Microbiol., 69, 3549-3560, 2003.

Magaard, L. and Rheinheimer, G.: Meereskunde der Ostsee, Springer-Verlag, Berlin, 1974.

Mendum, T. A., Sockett, E., and Hirsch, P. R: The detection of Gram-negative bacterial mRNA from soil by RT-PCR, FEMS Microbiol. Lett., 164, 369-373, 1998.

Meyer-Reil, L.-A. and Köster, M.: Eutrophication of marine waters: Effects on benthic microbial communities, Mar. Pollut. Bull., 41, 255-263, 2000.

Nausch, G., Matthäus, W., and Feistel, R.: Hydrographic and hydrochemical conditions in the Gotland Deep area between 1992 and 2003, Oceanologia, 45, 557-569, 2003.

Ogram, A.: Isolation of nucleic acids from environmental samples, in: Techniques in microbial ecology, Oxford Universtiy Press, 1998.

Osborn, C, Rees, G. N., Bernstein, Y., and Jansen, P. H.: New threshold and confidence estimates for terminal restriction length polymorphism analysis of complex bacterial communities, Appl. Environ. Microbiol., 72, 1270-1278, 2006.

Priemé, A., Braker, G., and Tiedje, J. M.: Diversity of nitrite reductase (nirK and nirS) gene fragments in forested upland and wetland soils, Appl. Environ. Microbiol., 68, 1893-1900, 2002.

Revsbech, N. P., Jørgensen, B. B., and Blackburn, T. H.: Microelectrode studies of the photosynthesis and $\mathrm{O}_{2}, \mathrm{H}_{2} \mathrm{~S}$, and $\mathrm{pH}$ profiles of a microbial mat, Limnol. Oceanogr., 28, 1062-1074, 1983.

Ricke, P., Kolb, S., and Braker, G.: Application of a newly developed ARB software-integrated tool for in silico terminal restriction fragment length polymorphism analysis reveals the dominance of a novel pmoA cluster in a forest soil, Appl. Environ. Microbiol., 71, 1671-1673, 2005.

Risgaard-Petersen, N., Meyer, R. L., Schmid, M., Jetten, M. S. M., Enrich-Prast, A., Rysgaard, S., and Revsbech, N. P.: Anaerobic ammonium oxidation in an estuarine sediment, Aquat. Microb. Ecol., 36, 293-304, 2004.

Rönner, U. and Sörensson, F.: Denitrification rates in the lowoxygen waters of the stratified baltic proper, Appl. Environ. Microbiol., 50, 801-806, 1985.

Santoro, A. E., Boehm, A. B., and Francis, C. A.: Denitrifier community composition along a nitrate and salinity gradient in a coastal aquifer, Appl. Environ. Microbiol., 72, 2102-2109, 2006.

Scala, D. J. and Kerkhof, L. J.: Horizontal heterogeneity of denitrifying communities in marine sediments by terminal restriction fragment length polymorphism analysis, Appl. Environ. Microbiol., 66, 1980-1986, 2000.

Sohlenius, G., Emeis, K.-C., Andren, E., Andren, T., and Kohly, A.: Development of anoxia during the Holocene fresh-water transition in the Baltic Sea, Mar. Geol., 177, 221-242, 2001.

Sohlenius, G., Sternbeck, J., Andren, E., and Westman, P.: Holocene history of the Baltic Sea as recorded in a sediment core from the Gotland Deep, Mar. Geol., 134, 183-201, 1996.

Taroncher-Oldenburg, G., Griner, E. M., Francis, C. A., and Ward, B. B.: Oligonucleotide microarray for the study of functional gene diversity in the nitrogen cycle in the environment, Appl. Environ. Microbiol., 69, 1159-1171, 2003.

Thamdrup, B. and Dalsgaard, T.: Production of $\mathrm{N}_{2}$ through anaerobic ammonium oxidation coupled to nitrate reduction in marine 
sediments, Appl. Environ. Microbiol., 68, 1312-1318, 2002.

Throbäck, I. N., Enwall, K., Jarvis, A., and Hallin, S.: Reassessing PCR primers targeting nirS, nirK, and nosZ genes for community surveys of denitrifying bacteria with DGGE, FEMS Microbiol. Ecol., 49, 401-417, 2004.

Tuomainen, J. M., Hietanen, S., Kuparinen, J., Martikainen, P. J., and Servomaa, K.: Baltic Sea cyanobacterial bloom contains denitrification and nitrification genes, but has negligible denitrification activity, FEMS Microbiol. Ecol., 45, 83-96, 2003.

Tuominen, L., Heinänen, A., Kuparinen, J., and Nielsen, L. P.: Spatial and temporal variability of denitrification in the sediments of the northern Baltic Proper, Mar. Ecol. Prog. Ser., 172, 13-24, 1998.
Voss, M., Liskow, I., Pastuszak, M., Ruess, D., Schulte, U., and Dippner, J. W.: Riverine discharge into a coastal bay: A stable isotope study in the Gulf of Gdansk, Baltic Sea., J. Marine Syst., 57, 127-145, 2005.

Weinbauer, M. G., Fritz, I., Wenderoth, D. F., and Höfle, M. G.: Simultaneous extraction from bacterioplancton of total RNA and DNA suitable for quantitative structure and function analysis, Appl. Environ. Microbiol., 68, 1082-1087, 2002.

Zumft, G.: Cell biology and molecular basis of denitrification, Microbiol. Mol. Biol. Rev., 61, 533-616, 1997. 